\title{
The Impact of Financial Development and Economic Growth on Environmental Quality of Kenya
}

\author{
Susan Moraa Onuonga \\ School of Economics, Kenyatta University, Kenya P.O .Box 33408-00600 Nairobi Kenya
}

\begin{abstract}
Of recent times many countries are suffering from environmental problems such as global warming and emission of greenhouse gases. Emissions of carbon dioxide as been recognized as the major contributor to global warming and climate change. This paper examines the long run relationship among the variables environmental quality, financial development and economic growth in Kenya using time series for the period 1970-2019. Autoregressive distributed lag bounds test is used to investigate long run relationship and Granger causality method is used to test for causality among the variables. Empirical results indicate that there is long-run relationship among the variables. Long run results suggest that increases in financial development, lagged $\mathrm{CO}_{2}$, energy consumption, population growth, and trade openness significantly worsens environmental quality in Kenya. Natural resources significantly improve environmental quality in Kenya. According to the results the relationship between $\mathrm{CO}_{2}$ and financial development in Kenya is non-linear suggesting presence of EKC between $\mathrm{CO}_{2}$ and financial development. The empirical results confirm that the Environmental Kuznets curve does not exist between $\mathrm{CO}_{2}$ and economic growth in Kenya in the long run. Short-run results also show that financial development, lagged $\mathrm{CO}_{2}, \mathrm{FDI}$, population growth, and trade openness increase $\mathrm{CO}_{2}$ emissions while natural resources reduce it. Causality results show unidirectional causality running from financial development to environmental quality and from $\mathrm{CO}_{2}$ to GDP. According to the findings, there is evidence of neutrality hypothesis between financial development in Kenya and economic growth. Existence of long run relationship suggests that the government of Kenya needs to implement appropriate environmental policies that reduce pollution during economic growth. The government should set policies and guidelines to the financial sector so that the sector offers credit to firms that reduce air pollution.
\end{abstract}

Keywords: Financial development, economic growth, $\mathrm{CO}_{2}$, Autoregressive distributed lag model, Kenya

JEL Classification: E44, C32, Q43, Q56

DOI: $10.7176 / \mathrm{JESD} / 11-12-03$

Publication date:June 30th 2020

\section{Introduction}

Global warming and climate change are the major environmental problems that have affected countries over several decades. These problems have attracted a lot of attention among researchers, academicians, economists and policy makers. Emission of green house gases especially carbon dioxide has been recognized as the major contributor to global warming and climate change. This is a major challenge facing economies (Zaman et al ,2016). Global warming has led to increases in global temperatures which have risen from $1.1^{\circ} \mathrm{C}$ to $6.5^{\circ} \mathrm{C}$ due environmental degradation (IPCC, 2014).Other effects are that countries have experiences rising sea levels, negative effects on farming and health of people leading to diseases such as allergies, asthma, infectious diseases and air pollution. Air pollution has several negative effects on health. it is the leading cause of respiratory diseases such as lung cancer, pulmonary heart disease and bronchitis ( Republic of Kenya ,2013).It has been observed that all these affect economic growth negatively and that high levels of carbon dioxide emissions reduce economic growth (Piaggio and Padilla, 2012). To reduce the effects of global warming emission of green house gases need to be reduced. For this to be effective the role of the factors that determine $\mathrm{CO}_{2}$ emissions need to be known.

Kenya`s economy grew by 6.3 percent in 2018 as compared to $4.9 \%$ in the year 2017 . This is attributed to improvement in agricultural sector, manufacturing, transport and the service sectors. In the year 2016, Kenya's economy grew by $5.9 \%$ as compared to $5.7 \%$ experienced in the year 2015 . At the same time Kenya's environment has been deteriorating as evidenced by high $\mathrm{CO} 2$ emissions. In spite of the effort done by the Kenya government to improve the environment quality, carbon dioxide emissions has increased over time In the year 2019 Kenya's $\mathrm{CO}_{2}$ emissions was 0.41 metric tons percapita, an increase of $41 \%$ as compared to the emissions in the year 2010 . The figure shows that on average from the year 2003, CO2 emissions have on average been increasing over time. This has happened in spite of the fact that Kenya has implemented several policies to improve the quality of the environment.

Kenya has created National Environment Management Authority (NEMA) whose role is to see the implementation of policies dealing with the environment and also to supervise all activities dealing with the environment. Kenya has also set up several policies aiming at sustaining the environment such as the sessional paper on forestry policy (Government of Kenya ,2007), Energy Act (Government of Kenya, 2005) and National environmental action plan (Government of Kenya, 1994). In spite of this effort, Kenya`s environment continues to deteriorate. 
Many studies have investigated the relationship between economic growths and environmental quality, little attention has been given to the impact of financial development. In Kenya there are very few studies that have looked on the impact of financial development on environmental quality. This study fills this gap by investigating the role of financial development on $\mathrm{CO}_{2}$ emissions within a multivariate framework.

The relationship between air pollution and economic growth theoretically according to Grossman and Krueger (1995) is non linear and graphically looks as an inverted U-shaped curve referred as Environmental Kuznets curve hypothesis. Many studies have been done arriving at mixed results. Several studies confirm the presence of EKC ( Mohammadi, 2016; Omri et al ,2015; Ozatac and Taspinar, 2017; AC et al 2018, AsumaduSarkodie and Owusu ,2017). If this is true then in the long run economies can improve the environment otherwise the environment will continue to deteriorate and Kyoto targets cannot be achieved. Other research findings show that EKC does not exist (Aye and Edoja, 2017; Simiyu, 2017; Mikayilov et al ,2018).

It is also possible as from a few studies that have been that financial sector can affect air pollution .Financial sector includes commercial banks, capital markets insurance companies and other financial intermediaries. A developed financial sector is one which is large enough and plays the following roles. Financial sector mobilizes and pools savings, allocates savings to the most productive use, provides information on possible investment, allocates capital, facilitates both domestic and international trade, manages risk, monitors firm`s activities and exerts corporate governance ( Mesagan and Nwachukwu ,2018). Development of the financial sector can accelerate economic growth and this will holding other factors constant affect environmental quality according to Environmental Kuznets curve (EKC) hypothesis. The industrial sector whose growth depends much on financing from the financial sector consumes a lot of energy in their industrial activities. Developing countries, Kenya inclusive mostly purchase energy intensive inputs which pollute the environment hence affecting the environment negatively ( Hoffmann, 2011). Financial intermediaries allocate credit to the private sector for investment and this can impact on the environmental quality negatively or positively (Mesagan et al, 2019). Through loans given to industry and factory activities and their energy consumption may increase pollution ( Sadorsky, 2010; Tamazian et al , 2009). Financial intermediaries can deny credit to those firms that are high in CO2 emissions and give more loans to those whose production processes emit less carbon dioxide and this can reduce $\mathrm{CO} 2$ emissions. It is also argued that financial intermediaries can access environmental friendly technologies which can reduce emissions of carbon dioxide ( Tamazian et al ,2009). Financial intermediaries also supply loans to consumers who purchase household appliances, refrigerators, houses among others. Household also buy air conditions and automobiles that increase air pollution ( Zhang , 2011). A developed financial facilitates investment with low cost including environmental friendly projects. A developed financial sector can reduce borrowing costs, promote investment in the energy sector and this will likely reduce pollution ( Tamazian et al ,2009, Tamazian and Rao, 2010). A developed financial sector attracts foreign direct investment. Foreign direct investment impact on a country`s economic growth which on the concept of EKC hypothesis affects the environment ( Tamazian and Rao, 2010).

Studies that have investigated the role of financial development on $\mathrm{CO} 2$ have obtained conflicting results. Some results indicate that financial developments worsens environmental quality ( Mohammadi , 2016; Mesagan and Nwachokwu, 2018; Moghadam and Dehbashi , 2018; Maji et al ,2017; Onanuga ,2017; Tsaurai, 2019; Phong, 2019). Some empirical results show that financial development improves environmental quality ( Shahbaz et al, 2013; Nazir et al ,2018; Jalil and Feridun, 2011; Basarir and Cakir, 2015; Onanuga ,2017). Lastly other empirical findings confirm neutrality hypothesis (Ayeche et al, 2016; Ghorashi and Rad ,2018; Rault , 2015; Omri et al ,2015; Mohammadi 2016).All these empirical findings suggest that the role of financial development is not yet a resolved issue.

This study adds to the current literature by investigating the role of financial development and economic growth on environmental quality in Kenya using data for the period 1970-2019. There are very few studies that have investigated the impact of financial development on $\mathrm{CO}_{2}$ in Kenya. This study will be beneficial to environment policy makers and the governments in making policies that are friendly to the environment.

The paper is organized as follows. Section 1.0 gives the introduction to the paper, section 2.0 presents literature review, section 3.0 discusses methodology, section 4.0 presents empirical findings while section 5.0 presents conclusions and policy implications of the paper.

\section{Literature Review}

Most of the studies have investigated the EKC hypothesis, which shows the relationship between economic growth and carbon dioxide emissions. The hypothesis argues that the relationship between $\mathrm{CO}_{2}$ and economic growth is quadratic in the long run (Grossman and Krueger, 1995). This graphically looks like an inverted U shape curve. Empirical studies that have been done over a few decades, present mixed results.

Ozatac and Taspinar (2017) investigated EKC for Turkey using the data for the period 1960-2013. The study used ARDL to test for presence of long run relationship and Granger and ECM to estimate short run relationship among the variables. The study found that EKC is applicable for Turkey and there is long run relationship among the variables included in the model. 
Simuyu (2017) investigated the presence of EKC and the impact of trade openness in Kenya. The research findings indicated that EKC hypothesis is not valid for the case of Kenya and that real GDP percapita has a negative impact on environmental quality.

Ogundipe and Oshin (2015), investigated the validity of EKC theory for West Africa countries. The study used static panel data approach for 15 West Africa counties for the period 1980-2012. The findings confirm the existence of EKC theory for the West Africa countries.

Shahbaz et al (2013) investigated whether financial development reduce $\mathrm{CO}_{2}$ in Malaysia. The study time series data for the period 1971-2008 and applied ARDL bounds to test for cointegration among the variables. The results indicated that financial development reduces $\mathrm{CO}_{2}$ emissions in Malaysia and that energy consumption and economic growth worsen environmental degradation.

Shahbaz et al (2013) studied the effects of financial development, economic growth, coal consumption and trade openness on environmental performance using time series data for the period 1965-2008 for Sub-Saharan Africa (SSA) countries. The study used ARDL bounds method to test for existence of long run relationship among the variables and ECM method to investigate the short run impact of the explanatory variables on quality of the environment. The findings confirm existence of cointegration among the variables and that economic growth and coal consumption increase energy emissions while financial development improve the quality of the environment. The study also confirmed existence of EKC in SSA.

Mohammadi (2016) investigated the impact of the major socio-economic variables as well as financial development on environmental quality using time series data over the period 1970-2013 for 16 middle income countries. The study used PSTR method. The findings of this study provided evidence that output and energy consumption have positive significant effect on environmental pollution but their effect at higher levels of financial development decrease and increase respectively. Population also affected $\mathrm{CO}_{2}$ emissions positively. Financial development has a significant positive effect on pollution with a threshold level of $34 \%$ for financial development index.

Omri et al (2015), studied the relationship between financial development, $\mathrm{CO}_{2}$ emissions, trade openness and economic growth using simultaneous equation panel data models for a panel of 12 MENA countries over the period 1990-2011. The study came up with several findings: the EKC hypothesis was confirmed for the 12 MENA countries, there is bidirectional causality between $\mathrm{CO}_{2}$ and economic growth, and between economic growth and trade openness.

Mesagan and Nwachukwu (2018) studied the determinants of environmental quality for Nigeria using data for the period 1981-2016. The study used ARDL bounds test for cointegration analysis and Granger causality for the causal relationship among the variables. The study found that income, financial development energy consumption and trade positively and significantly determine air pollution.

Tsauri(2019) on the study on the role of financial development on carbon dioxide emissions for west Africa countries found that financial development significantly increase carbon dioxide emissions in West Africa countries. The study used time series data for the period 2003-2014 and applied pooled ordinary least squares method, fixed and random effects methods.

From the theoretical arguments and empirical findings, the impact and the relationship between carbon dioxide, economic growth and financial development is not conclusive. Theoretically financial development can worsen environmental quality and it can also improve it. The relationship between $\mathrm{CO} 2$ and financial development can be linear or non-linear. Most of the studies have found that economic growth increase pollution of the country, however the hypothesis of EKC is present in some studies while some studies invalidate this hypothesis.

This study contribute to the present knowledge by studying the impact of financial development and economic growth on carbon dioxide emissions using ARDL bounds test method to test for the presence of long run relationship among the variables $\mathrm{CO} 2$, energy consumption, economic growth, financial development, foreign direct investment, natural resource, population and trade. The short run coefficients are estimated by use of ECM and causality analysis is done by use of Granger causality method. The study uses Kenyan time series data for the period 1970-2019.

\section{Methodology}

This paper uses econometrics analysis to investigate long run relationship and causality among the variables financial development, economic growth energy consumption, natural resources, foreign direct investment, population growth, trade openness, and environmental quality in Kenya using time series data for the period 19702019.The paper uses ARDL to investigate long run relationship while Granger causality test is used to test for causality among variables. Data for these variables are obtained from World Bank development indicators, Kenya economic survey and Kenya statistical abstract.

In this paper the level of carbon dioxide $\left(\mathrm{CO}_{2}\right)$ emissions in Kenya over years is taken as a proxy of environmental quality.

$\mathrm{CO}_{2}$ emissions function is modeled as: 
Where $\mathrm{CO}_{2}$ is carbon dioxide emissions (metric tons per capita), FD represents financial development ( proxied by credit to the private sector), and $\mathrm{Y}$ economic growth of Kenya while $\mathrm{E}$ is energy consumption per capita. The square of financial development was also included in the model to find out whether the relationship between $\mathrm{CO}_{2}$ and financial development is non -linear or not. The logic behind this is that the financial sector cares less for the environment in the earlier stages of economic growth. When the economy matures, the developed financial sector's activities will improve the quality of the environment by issuing loans to environmentally friendly projects (Shahbaz, Solarin, Mahmood ,and Arouri, 2013). In this model foreign direct investment is also included as an explanatory variable to measure the impact of foreign capital on $\mathrm{CO}_{2}$ emissions. Kenya`s foreign direct investment has been growing over time and with a developed financial sector foreign direct investment my invest in environmental friendly projects that may reduce greenhouse gases emissions (Talukdar, and Meisner, 2001). Other variables that have been identified in the literature include population growth (POP) ,natural resources (NR) and trade openness (TR). As the population of a country increases, it engages in deforestation and increases its demand for energy for their various activities. This will worsen global warming of the country as the emissions of carbon dioxide increase (Tsaurai, 2019). Exploitation of natural resources such as drilling of oil needs usage of heavy machinery which consumes a lot of energy impacting positively to air pollution (Kwakwa et al 2018). Trade openness affects environmental quality, as countries engage in international trade they increase imports of industrial inputs which are high energy consuming and this may increase air pollution in the country. Therefore to include all these variables the above model becomes

$$
C O_{2 t}=f\left(F D_{t}, F D_{t}^{2}, Y_{t}, E_{t}, F D I_{t}, N R_{t}, P O P_{t}, T R_{t}\right)
$$

Since quite a number of studies have validated the presence of $\mathrm{EKC}$ between $\mathrm{CO}_{2}$ and income, the above model (2) incorporated the square of income to find out if it is present in Kenyan context. Therefore model (2) was also estimated with $\mathrm{Y}$ squared without the financial development squared as:

$$
C O_{2 t}=f\left(F D_{t}, Y_{t}, Y_{t}^{2} E_{t}, F D I_{t}, N R_{t}, P O P_{t}, T R_{t}\right)
$$

In the model the indicator of environment quality is $\mathrm{CO}_{2}$ which represents total carbon dioxide emissions in Kenya measured in metric tons percapita. FD is financial development which is proxied by total domestic credit to the private sector expressed as \% of GDP, $\mathrm{FD}^{2}$ is financial development squared, Y represents economic growth in Kenya, $\mathrm{Y}^{2}$ this is economic growth squared, E represents energy consumption percapita, FDI represents foreign direct investment expressed as \% of GDP, NR is natural resources measured by natural rent expressed as a percentage of GDP, POP is population growth expressed as a percentage of total population TR is trade openness which are total exports and imports expressed as \% of GDP. All variables are converted to natural logarithms. The empirical equation is expressed as:

$$
\begin{aligned}
\operatorname{InCO}_{2 t}=\alpha+ & \beta_{f d} \operatorname{InFD}_{t}+\beta_{f d^{2}} \operatorname{InFD}_{t}{ }_{t},+\beta_{Y^{2}} \operatorname{In} Y_{t}+\beta_{E} \operatorname{InE}_{t}+\beta_{f d i} \operatorname{InFDI}_{t},+ \\
& \beta_{N R} \operatorname{InNR}_{t}+\beta_{p o p} \operatorname{InPOP}_{t}+\beta_{T R} \operatorname{InTR}_{t}+u_{t} \\
\operatorname{InCO}_{2 t}=\alpha+ & \beta_{f d} \operatorname{InFD}_{t}+\beta_{Y} \operatorname{InY}_{t},+\beta_{Y^{2}} \operatorname{InY}_{t}^{2}+\beta_{E} \operatorname{InE}_{t}+\beta_{f d i} \operatorname{InFDI}_{t},+ \\
& \beta_{N R} \operatorname{InNR}_{t}+\beta_{p o p} \operatorname{InPOP}_{t}+\beta_{T R} \operatorname{InTR}_{t}+u_{t}
\end{aligned}
$$

The coefficient of FD $\beta_{\mathrm{fd}}$ as from previous studies it can be positive or negative. In case of presence of EKC between $\mathrm{CO}_{2}$ and $\mathrm{FD}$, then the coefficient of $\mathrm{FD}^{2}$ is supposed to be negative. The coefficient of economic growth $\beta_{\mathrm{y}}$ is supposed to be positive, as economic activities increase pollution is supposed to increase. The coefficient of the square of income $\beta \mathrm{y} 2$ is supposed to be negative if EKC is valid as for the relationship between $\mathrm{CO}_{2}$ and income. That is after a certain threshold the quality of the environment is supposed to start improving as according to $\mathrm{EKC}$ hypothesis that is to produce an inverted $\mathrm{U}$ shaped curve. The coefficient of energy consumption is supposed to be positive. As counties develop they increase consumption of energy, this increases emissions of $\mathrm{CO}_{2}$ (Jalil and Feridun, 2011) holding other factors constant. The coefficient of FDI is expected to be positive as investment increases economic growth increases and this leads to more pollution to the environment (Tamazian and Rao, 2010). The coefficient of natural resources $\beta_{\mathrm{NR}}$ is expected to be positive. The logic behind this is that as the country exploits more natural resources, the demand for energy increases this worsens environmental degradation as more GHS gases are emitted to the environment (Kwakwa et al 2018). At the same time during natural resource exploitation heavy machinery are used which consume more energy there increasing air pollution. As the population of the country increase the demand for goods and services increase including demand for automobiles. High population also engages in deforestation. The increase in demand for automobiles and increase of deforestation impacts positively to air pollution therefore the coefficient of pop $\beta_{\text {pop }}$ is expected to be positive. Lastly the coefficient of trade openness is expected to be positive or negative. As the country engages more in international trade, more inputs to the industrial sector are imported which emit more carbon dioxide hence 
worsening environment quality. It is also possible that with expansion of trade countries can access environmental friendly inputs in the international market that may reduce CO2 emission (Grossman and Krueger, 1991).

To test for existence of long run relationship among the variables this paper uses ARDL bounds test for cointegration. This method is applicable for small samples and cases where the variables are $\mathrm{I}(0)$ or $\mathrm{I}(1)$ or a mix of the two levels of integration(Nkoro \&Uko, 2016; Pesaran, Shin \&Smith, 2001).

Testing for long run relationship, the ARDL bounds testing approach for cointegration involves two steps. The first step is to investigate existence of long run relationship among all the variables in the model. This involves estimating a dynamic error correction model computed from ARDL through a simple linear transformation. The unrestricted form of the ECM of the ARDL model is expressed as:

$$
\begin{aligned}
& \Delta \operatorname{InCO} \mathrm{C}_{2 t}=a_{0}+\sum_{i=1}^{p} \beta_{i} \Delta \operatorname{InCO} O_{2 t-i}++\sum_{i=0}^{q 1} \alpha_{i} \Delta \operatorname{InFD_{t=i}}+\sum_{i=0}^{q 2} c_{i} \Delta \operatorname{InFD_{t-i}^{2}}+\sum_{i=0}^{q 3} d_{i} \Delta \operatorname{In} Y_{t-i} \\
& +\sum_{i=0}^{q 4} \gamma_{i} \Delta \operatorname{In} E_{t-i}+\sum_{i=0}^{q 5} \pi_{i} \Delta \operatorname{InFDI} I_{t-i}+\sum_{i=0}^{q 6} r_{i} \Delta \operatorname{InNR} R_{t-i}+\sum_{i=0}^{q 7} e_{i} \Delta \operatorname{InPOP} P_{t-i}+\sum_{i=0}^{q 8} k_{i} \Delta \operatorname{InTR} R_{t-i}+ \\
& \sigma_{1} \operatorname{InCO}_{2 t-1}+\sigma_{2} \operatorname{InFD}_{t-1}+\sigma_{3} \operatorname{InFD} D_{t-1}^{2}+\sigma_{4} \operatorname{In} Y_{t-1}+\sigma_{5} \operatorname{In} E_{t-1}+\sigma_{6} \operatorname{InFDI} I_{t-1}+\sigma_{7} \operatorname{InNR} R_{t-1}+\sigma_{8} \operatorname{InPOP} P_{t-1} \\
& \sigma_{9} \operatorname{InTR}_{t-1}+u_{t}
\end{aligned}
$$

Equation (6) was also expressed with $\mathrm{Y}^{2}$ instead of $\mathrm{FD}^{2}$ to test for EKC. $\Delta$ is the first difference operator $\beta_{i}, \delta_{i}, \alpha_{\mathrm{i}}, \mathrm{c}_{\mathrm{i}} \mathrm{d}_{\mathrm{i}}, \gamma_{i}, \pi_{i} \mathrm{r}_{\mathrm{i}}, \mathrm{e}_{\mathrm{i}}, \mathrm{k}_{\mathrm{i}}$, are coefficients of short run dynamic model, $\sigma_{\mathrm{i}}$ are long run parameters of the model and $\mathrm{u}_{\mathrm{t}}$ are white noise errors. To perform the bounds test the following hypothesis is tested:

$\mathrm{H}_{0}: \sigma_{1}=\sigma_{2}=\sigma_{3}=\sigma_{4}=\sigma_{5}=\sigma_{6}=\sigma_{7} \sigma_{8} \sigma_{9=0}$ (long run relationship does not exist),

$\mathrm{H}_{1}: \sigma_{1} \neq \sigma_{2} \neq \sigma_{3} \neq \sigma_{4} \neq \sigma_{5} \neq \sigma_{6} \neq \sigma_{6} \neq \sigma_{6} \neq \sigma_{6} \neq 0 \quad$ ( long run relationship exists).

Once the test is done, if one fails to reject the null hypothesis then we conclude that there is no cointegration in the series, however if the null hypothesis is rejected then we conclude that there is cointegration in the series.

The decision is based on the calculated F statistic which is derived from the Wald test is compared with the critical values of Pesaran et al.(2001). Pesaran et al (2001) have provided critical values which guides one on failing to reject the null hypothesis or not. The critical values are two for each level of significant (the lower and the upper critical values). If the F-statistics value is lower than the lower bound critical value of Pesaran et al (2001), then it is concluded that there is no long run relationship among the time series variables considered in the model. If the computed F- statistic value falls between the lower and upper critical values of Pesaran et a.(2001), then there is no conclusion made on the relationship among the variables. However, if the estimated F- statistics is above the upper bound critical value of the Pesaran et al (2001), one concludes that there is long run relationship among the variables included in the model. If cointegration is established the error correction model is estimated which is expressed as:

$$
\begin{aligned}
& \Delta C O_{2 t}=a_{0}+\sum_{i=1}^{p} \beta_{1 i} \Delta \operatorname{InCO} O_{2 t-1}+\sum_{i=0}^{q 1} \beta_{2 i} \Delta \operatorname{InFD} D_{t-i}+\sum_{i=0}^{q 2} \beta_{3 i} \Delta \operatorname{In} Y_{t-i}+\sum_{i=0}^{q 3} \beta_{4 i} \Delta \operatorname{In} E_{t-k}+\sum_{i=0}^{q 4} \beta_{5 i} \Delta \operatorname{InFDI} I_{t-i} \\
& +\sum_{i=0}^{q 5} \beta_{5 i} \Delta \operatorname{InNR} R_{t-i}+\sum_{i=0}^{q 6} \beta_{6 i} \Delta \operatorname{InPOP} P_{t-i}+\sum_{r=0}^{q 5} \beta_{7 i} \Delta \operatorname{InTR} R_{t-r}+\lambda E C T_{t-1}
\end{aligned}
$$

Where $\beta_{i j}$, are short term parameters, while $\lambda$ is the error correction coefficient which shows the speed of adjustment of the dependent variable to its equilibrium value when a shock occurs in the system while ECT are the residuals obtained from the estimated equation (6).

\section{Empirical Results}

\subsection{Descriptive Statistics}

The descriptive statistics for the variables included in the empirical model is presented in Table I in the appendix

\subsection{Unit Root Tests}

To test for unit root in this paper, Augmented Dickey- Fuller (ADF) and PP test of Phillips and Perron (1988) are used. This is done to confirm that all variables were $\mathrm{I}(0)$ and $\mathrm{I}(1)$ only since ARDL is applicable for the cases of variables which are $\mathrm{I}(0)$ and $\mathrm{I}(1)$ only and not $\mathrm{I}(2)$. The unit results are shown in Table II in the appendix.

To obtain lag length of the variables the Akaike Information Criteria (AIC) was used. According to the results in Table2, foreign direct investment and economic growth were found to be stationary at levels while carbon 
dioxide emission, financial development, energy consumption, natural resources, population growth and trade were found to be stationary at their first differences. Since the variables were a mix of I(0) and I(1), the ARDL bounds test was therefore found to be applicable. The results for ARDL bounds test are presented in Table III in the appendix.

The ARDL bounds test was done to investigate the existence of long-run relationship among the variables in the model. The F statistic tests the joint null hypothesis which assumes that the coefficients of all lagged variables at levels is equal to zero meaning that there is no long run relationship among the variables. In testing for this hypothesis, each variable was assumed to be a dependent variable. The results shown in Table 3 shows that there is contegration when, financial development, foreign direct investment, economic growth and natural rent are dependent variables. Financial development, foreign direct investment and economic growth were significant at one percent as their respective F - statistic values $(5.6,6.3,4.7)$ exceeded the Pesaran et al (2001) upper critical values while natural rent function with an F-statistic value of 3.38 was significant at five percent level. With these ARDL bounds test result for the four functions, the null hypothesis which states that there is no cointegration was rejected. The results in Table 3 confirm that there is no cointegration when carbon dioxide emissions, energy consumption, population growth and trade are dependent variables. Their F statistic values ( $1.4,1.88$. 1.80 and 2.35) were found to be below the Pesaran et al (2001) lower critical values. The null hypothesis which states that there is no cointegration was not rejected. The diagnostics results shown in column three of Table III, shows that the error term obeys all the OLS assumption. The Johansen and Juselius (1990) cointegration test was done to confirm the ARDL bounds test results. Table IV presents the Johansen cointegration test results.

The trace statistic suggest presence of five cointegrating equations at the 0.05 level while maximum eigen value statistic shows presence of two cointegrating equations. Following confirmation of existence of cointegration the long run equation was estimated which gave the results in Table V.

Two models are estimated, the first one included financial development squared to find out whether the relationship between financial development and $\mathrm{CO}_{2}$ is inverted U-shaped or not and the second model had economic growth squared also to check if EKC exists between $\mathrm{CO}_{2}$ and income. All variables were expressed in natural logarithm form. Financial development has a positive effect in model one while in model two it has a negative impact. In model one if financial development increases by one percent, $\mathrm{CO}_{2}$ increase by 4.12 percent. This result was statistically significant at 1 percent. The square of financial development shows a significant negative impact on $\mathrm{CO}_{2}$. The significant negative impact of the square of financial development on environmental quality, shows that the relationship between environmental quality and financial development is non-linear. The environmental Kuznets curve exists between environmental quality and financial development. Kwakwa(2018), found existence of EKC on the relationship between $\mathrm{CO}_{2}$ and financial development.

In both models the coefficients of $\mathrm{CO}_{2}$ lagged, energy consumption and natural rent were statistically significant at one percent. The results suggest that if lagged carbon dioxide emissions increase by 1 percent, carbon dioxide emissions will increase by about 0.3 per cent in model one and around 0.4 percent in model two. This result was statistically significant.

Energy consumption in both models has a positive impact on environmental quality. Increase of energy consumption by one percent worsens environmental quality by 2.54 percent in model one and 1.96 percent in model 2, respectively. Both coefficients were statistically significant at 1 percent. Increases foreign direct investment worsens environmental quality in Kenya. An increase of foreign direct investment by one percent increases $\mathrm{CO}_{2}$ by 0.017 percent in model one. An increase in natural rent in both models improves environmental quality. An increase of natural rent by one percent reduces carbon dioxide emissions by 0.18 percent in model one, and by 0.145 in model two. Both coefficients were statistically significant at 1 percent. Growth in population and trade openness worsens environmental quality in Kenya during the sample period. Growth in Kenya`s population by 1 percent increases $\mathrm{CO}_{2}$ emissions by 0.21 per cent while growth in trade openness by 1 percent increases $\mathrm{CO}_{2}$ emissions by 0.19 percent. The population growth coefficient was statistically significant at five percent while the trade openness coefficient was statistically significant at one percent in model one. From the long run results EKC theory, for the relationship between $\mathrm{CO}_{2}$ and economic growth does not exist for the case of Kenya. This result was also found by (Simiyu, 2017). The diagnostic tests done for the error term shows that the two models estimated was sound. The results in Table VI shows short run estimated coefficients of the model. Figure II, shows the plot of the CUSUM of squares.

According to the results in Table VI, increase in financial development, energy consumption, foreign direct investment, population growth and trade significantly worsens environmental quality in Kenya in the short run during the study period. However, increases in natural rent holding after factors constant, improves environmental quality in nature as its coefficient (-0.011) is statistically significant at one percent. The error correction coefficient has a negative significant coefficient (-0.70). The results suggest that short run deviations of $\mathrm{CO}_{2}$ from its long run value were corrected about 70 percent each year. The significant ECT coefficient also confirms existence of long run relationship among variables in the model. The model passed all the diagnostic tests of the error term .The plot of the CUSUM of squares in Figure I, shows that the estimated coefficients are stable in the entire sample 
period. Table VII, shows Granger causality analysis results.

From the Granger causality results there is unidirectional causality running from financial development to environmental quality. The $\mathrm{F}$-statistic 3.59 is statistically significant at ten percent. There is also unidirectional causality running from $\mathrm{CO}_{2}$ to GDP. CO2 emissions Granger causes GDP. The F- statistics 3.39 is statistically significant at ten per cent. Neutrality hypothesis is confirmed between financial development and GDP in the sample period.

\section{Conclusion and policy recommendations}

This paper investigated the relationship among environmental quality, financial development and economic growth in Kenya. The paper used ARDL bounds test to test for long run relationship among the variables. Time series data for the period 1970-2019 was used. The paper found that there is long run relationship when financial development, foreign direct investment, economic growth and natural rent are dependent variables. The paper found that financial development significantly worsens environmental quality in model one and that there is existence of EKC between environmental quality and financial development. Long run results show that in both models increases in lagged $\mathrm{CO}_{2}$, and energy consumption worsen environmental quality while increases in natural rent improve environmental quality. Other variables that significantly worsen environmental quality are foreign direct investment, population growth and trade openness .As the country increases its international trade, and foreign direct investment, $\mathrm{CO}_{2}$ emissions increase. Growth in population as it increases its energy consumption, destroys forests and its increase in demand for industrial products, emission of greenhouse gases increase all these degrades the environment. From the results EKC does not exist between $\mathrm{CO}_{2}$ and economic growth in Kenya during the sample period Short-run results confirm that increases in financial development energy consumption foreign direct investment trade and population growth worsen environmental quality while natural rent improve $\mathrm{CO}_{2}$.

Causality results indicate that there is unidirectional causality running from financial development to $\mathrm{CO}_{2}$ emissions and from $\mathrm{CO}_{2}$ emissions to GDP.

The conclusions of this paper are that financial development, energy consumption, population growth, trade openness, and foreign direct investment impact on environmental quality negatively while natural resources improve air pollution in Kenya. The hypothesis of EKC for the relationship between income and air pollution is not valid in Kenya, however it is applicable for the relationship between air pollution and financial development.

The policy implication of the paper findings suggest that the government of Kenya should come up with policies that make sure that the loans given by financial sector are investment in environment friendly projects in the short run however in the long run as the financial sector develops pollution will go down without much effort by the government. Appropriate policies should be implemented to control population growth as the results show that high population worsens $\mathrm{CO}_{2}$ emissions. The government and all stake holders should increase investment in clean energy as this is known to pollute less the environment. Foreign direct investment flows to be invested more on environment friendly projects. Lastly as the country engages more in foreign trade, the government should put in place policies that inhibit importation of inputs that increase pollution.

\section{References}

AC, M., JA, F., \& PA, L. (2018). The impact of economic growth on $\mathrm{CO}_{2}$ emissions in Australia: The environmental Kuznets curve and the decoupling index. Env and sc pollut Res Int 25(27) 27283-27296.

Ali, H.S., Law, S.H., Lin, W.L. et al. (2019). Financial Development and carbon Dioxide emissions in Nigeria: evidence from the ARDL bounds approach. GeoJournal 84, 641-655.

Asumadu-Sarkodie, S.M., \& Owusu, P.A. (2017). Carbon dioxide emissions, GDP percapita, industrialization and Population: An Evidence from Rwanda. Environmental engineering research, 22(1) 116-124.

Aye, G. C., \& Edoja, P.E (2017) . Effect of economic growth on CO2 emission in developing countries: Evidence from a dynamic panel threshold model. Cogen economics and finance, 5(1) 1379239-137.

Ayeche, M.B, Barhoumi, M., Hammas M.A.(2016) . Causal linkage between Economic Growth Financial Development, Trade openness and $\mathrm{CO} 2$ emissions in European countries. American Journal of Environmental Engineering, 6(4) 110-122.

Basarir,C.,\& Cakir,. N.(2015).Causal interactions between CO2 emissions , Financial development, energy and Tourism. Asian economic and financial review, 5(11) 1227- 1238

Bese, E. \& Kalayci, S. (2019). Testing the environmental KuznetsCurve hypothesis: Evidence from Egypt, Kenya and Turkey. International journal of energy economics and policy, 9(6) 479-491.

Chang, C. C.(2010).A multivariate causality test of carbon dioxide emissions, energy consumption and economic growth in China. Applied Energy, 87(11), 3533-3537.

Dasgupta, S., Laplante, B., \& Mamingi, N. (2001). Pollution and capital markets in developing countries. Journal of Environmental Economics \& Management, 42, 310-335.

Hoffimann, U.(2011). Some reflections on climate change, Green growth Illusions and Development Space. 
Discussion Paper No 205. New York : United Nations Conference on Trade and Development (UNCTAD).

Ghorashi, N.,\& Rad A.A (2018). Impact of Financial development on $\mathrm{CO}_{2}$ Emissions: Panel data evidence from Iran`s economic sectors. Journal of community Health research, 7(2) 127- 133.

Ghosh, S. (2010). Examining Carbon Emissions, Economic growth nexus for India: A multivariate cointegration approach. Energy Policy, 38(6), 3008-3014. Government of Kenya (2013). Natural environmental policy 2013. Gorvenment Printer Nairobi

Government of Kenya. (Various issues (a)): The Economic Survey. Nairobi: Government Printer.

Government of Kenya. (Various issues (b)): Statistical Abtract. Nairobi: Government Printer.

Government of Kenya. 1994. National Environmental Action Plan - NEAP 1994. Nairobi, Kenya: Government Printer.

Government of Kenya. 2007. Sessional paper on forest policy. Nairobi, Kenya: Government Printe

Government of Kenya. 2005. EnergyAct 2006. Nairobi, Kenya: Government Printer

Grossman, G.,M \& Krueger, A.B.(1991). Environmental impact of a North America Free trade agreement NBER working paper 3914 p1-57.

Grossman G.M \& Krueger A.B (1995) . Economic growth and the Environment. The quarterly Journal of economics, $110353-377$

Jalil ,A. \& Feridun, M. (2011) .The impact of growth, energy and Financial development on the Environmental in China: A cointegration analysis . Energy economics, 33(2) 284-291.

Kwakwa,P.A., Alhasan, H.,Adu, G (2018). Effect of natural Resources extraction on Energy consumption and Carbon dioxide emission in Ghana, Munich Pernal RePEc Archive (MPRA) paper number 85401 p 1-19.

Kwakwa, P.A. Alhassan, H. \& Aboahye , S.(2018). Environmental Kuznets curve hypothesis in aFinancial Development and natural resource extraction context: evidence from Tunisia. Quantitative Finance and Economics, pp981-1000.

Frankel, J.,\& Romer, D. (1999). Does trade cause growth?. American Economic Review, 89, 379-399

Talukdar, D., \&Meisner, C.M.(2001).Does the private sector help or hurt the environment? Evidence from carbon dioxide pollution in developing countries. World Development29, 827-840.

Tamazian, A., Piñeiro, J., \& Vadlamannati, K. C. (2009). Does higher economic and financial development lead to environmental degradation: Evidence from BRIC countries. Energy Policy, 37 (1), 246-253.

Tamazian A. Rao B.B.(2010). Do economic financial and Institutional Developments matter for environmental degradation? Evidence from transitional economies .Energy Economics ,32(1) pp 137-145

Tsaurai K.(2019) Impact of Financial development on CO2 in Africa . International Journal of Energy Economics and Policy, 93 144-153.

Zaman K, Shahbaz,M., Loganahan N, \& Raza, S.A (2016). Tourism development energy consumption and environment Kuznets Curve: Trivariate analysis in the panel of developed and developing countries. Tourism management, 54 275-283.

Zhang,Y. J. (2011). The impact of financial development on Carbon emissions: An empirical analysis in China. Energy policy, 39(4) pp 2197-2203.

Mahalik M.K, Babu M.S \& Loganathan N. (2017) Does financial development intensify energy consumption in Saudi Arabia. Renewable and sustainable energy reviews . 75, 1022- 1034.

Maji, I.K., Habibullah, M.S. \& Saari, M.Y. (2017.) Financial development and Sectoral $\mathrm{CO}_{2}$ emissions in Malaysia. Environ Sci Pollut Res 24, 7160-7176.

Mesagan, E. P \& Nwachukwu M.I. (2018). Determinants of environmental quality in Nigeria: Assessing the role of Financial development . Econometric Research in Finance. Vol 3, 55-78.

Mesagan, E.P., Isola, W.A. \& Ajide, K.B. (2019). The capital investment channel of environmental improvement: evidence from BRICS. Environmental Development and Sustainability 21, 1561-1582.

Mikayilov J., Geleotti M \& Hasanov F (2018). The impact of economic growth on CO2 emissions in Azerbaijan . Journal of cleaner production, 197(1) 1558-1572.

Moghadam, H.E \& Dehbashi, V .(2018). The impact of financial development and Trade on environmental quality in Iran. Empirical economics,54(4) 1777-1799.

Mohammadi , $\mathrm{T}$ (2016). Economic Growth, Financial development and $\mathrm{CO}_{2}$ Emission: PSTR Approach Iranian. Journal of economic studies, 5(2) 145-171.

Nazir, M.R, Nazir, M.I., Hashmi ,S.H \& Fareed Z (2018). Financial development, Income, Trade and Urbanization on $\mathrm{CO}_{2}$ Emissions: New Evidence from Kyoto Annex countries. Journal on innovation and sustainability. 9(3) 17-36.

Nkoro, E \& Uko , K (2016). Autoregressive Distributed lag (ARDL) Cointegration technique: Application and Interpretation. Journal of Statistical and Econometric methods, 5 (4 ) 63- 91.

Nosheen, M., Iqbal, J. \& Hassan, S.A(2019). Economic growth, financial development, and trade in nexuses of $\mathrm{CO}_{2}$ emissions for Southeast Asia. Environ Sci Pollut Res 26, 36274-36286 . https://doi.org/10.1007/s11356019-06624-7 
Odhiambo N.M. (2017). $\mathrm{CO}_{2}$ emissions and economic growth in Sub-Saharan Africa countries. A panel data analysis. International Area studies review,20(3) 264-272.

Ogundipe , A. \& Oshin S.(2015). An Empirical examination of Environmental Kuznets Curve in West Africa. Euro-Asian Journal of Economics and Finance, 3(1) 18-28.

Omri .A., Saida, D. Rault C , \&Chaibi A. (2015) . Financial development, environmental quality, Trade and Economic growth: What causes what in MENA countries. IZA discussion paper number 8868 .

Onanuga O.T (2017). The impact of economic and financial development on Carbon Emissions: Evidence from Sub-saharan Africa. University of South Africa, unpublished Doctoral thesis.

Ozatac N \& Taspinar N (2017). Testing the EKC hypothesis by considering trade openness, urbanization, and financial development: The case of Turkey. Environmental science and Pollution research 24 (12)

Pesaran, M.H., Shin Y., and Smith, R.J (2001). Bounds testing approaches to the analysis of level relationship. Journal of applied econometrics, 16, 289-326.

Piaggio, M.,\& Padilla E.( 2012). CO2 emissions and Economic Activity: Heterogeneity across countries and nonstationary series. Energy policy 46, 370-381.

Phong, L.H. (2019) .Globalization, financial development and environmental degradation in the presence of environmental Kuznets curve: Evidence from ASEAN-5 countries . International journal of Energy Economics and Policy 9(2) 40-50

Rault, C.( 2015).Financial development, environmental quality, Trade and economic growth : What causes what in MENA countries. IZA Discussion paper number 8868

Sadorsky, P. (2011).Financial development and energy consumption in Central and Eastern European frontier economies. Energy policy, 39(2) 999-1006.

Shahbaz M,. Solarin S.A., Mahmood H., \& Arouri,M. ( 2013) Does Financial development reduce CO2 emissions in Malaysia Economy A time series Analysis . Economic modeling vol 35 145-152.

Shahbaz M., Tiwari, A.K., \& Nasir M, (2013). The effects of financial development development, economic growth coal consumption and trade openness on CO2 emissions in South Africa. Energy policy, 61 14521459.

Simuyu , H,N (2017). Environmental quality, trade openness and economic growth in Kenya: an implication of the Environmental Kuznets curve.M.A thesis UON

World Development Indicators (2019) https://databank.worldbank.org/source/world- development-indicators

Appendix: List of Tables and Figures

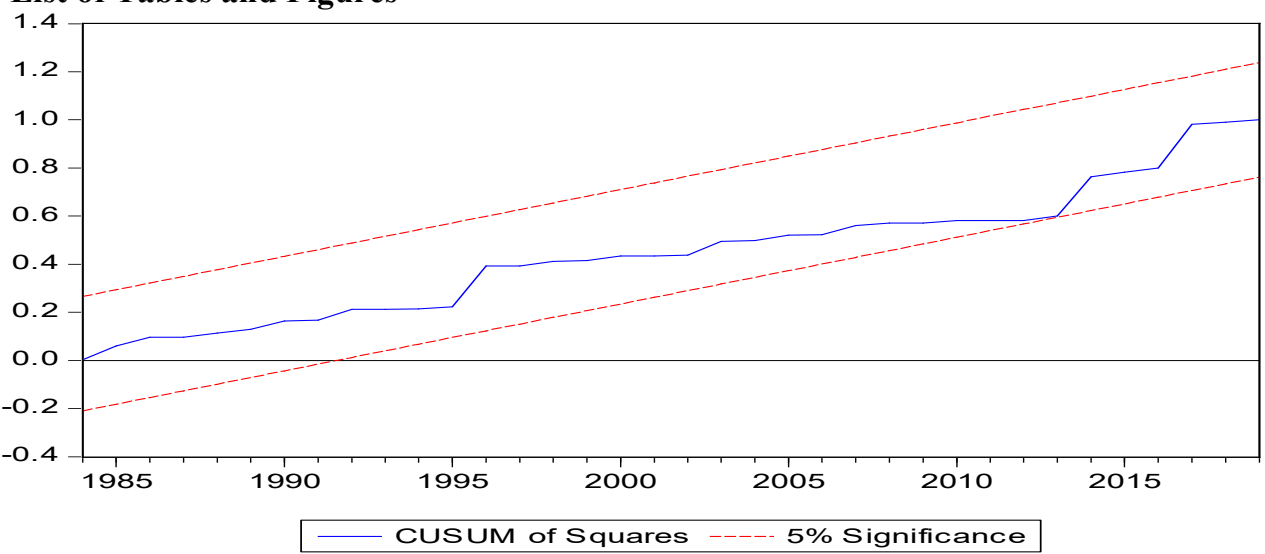

Figure I :Plot of CUSUM of squares test for short run model

Source: study data 
Table I: descriptive statistics

\begin{tabular}{|l|l|l|l|l|l|l|l|l|}
\hline & $\operatorname{In}(\mathrm{CO} 2)$ & $\operatorname{In}(\mathrm{CRD})$ & $\operatorname{In}(\mathrm{ENERGY})$ & $\operatorname{In}(\mathrm{FDI})$ & $\operatorname{In}(\mathrm{GDP})$ & $\operatorname{In}(\mathrm{NATURAL}$ RENT) & $\operatorname{In}(\mathrm{POP})$ & $\operatorname{In}(\mathrm{TRADE})$ \\
\hline Mean & -1.24 & 3.13 & 6.13 & -0.59 & 1.25 & 1.33 & 1.12 & 4.018 \\
\hline Median & -1.24 & 3.13 & 6.12 & -0.63 & 1.5 & 1.32 & 1.06 & 4.02 \\
\hline Maximum & -0.89 & 3.54 & 6.25 & 1.25 & 3.098 & 1.98 & 1.35 & 4.31 \\
\hline Minimum & -1.61 & 2.79 & 6.06 & -3.29 & -1.47 & 0.85 & 0.83 & 3.58 \\
\hline Std. Dev. & 0.16 & 0.21 & 0.05 & 0.95 & 0.95 & 0.27 & 0.16 & 0.16 \\
\hline Skewness & 0.19 & 0.26 & 1.43 & -0.25 & -1.049 & 0.32 & 0.023 & -0.85 \\
\hline Kurtosis & 2.79 & 2.01 & 4.046 & 2.99 & 3.88 & 2.68 & 1.54 & 3.92 \\
\hline Jarque-Bera & 0.37 & 2.43 & 17.78 & 0.48 & 10.14 & 1.025 & 4.16 & 7.44 \\
\hline Probability & 0.83 & 0.29 & 0.000137 & 0.78 & 0.006 & 0.59 & 0.12 & 0.024 \\
\hline Sum & -58.44 & 147.06 & 287.98 & -27.96 & 58.82 & 62.64 & 52.94 & 188.85 \\
\hline Sum Sq. Dev. & 1.21 & 1.94 & 0.14 & 41.46 & 42.35 & 3.415 & 1.32 & 1.32 \\
\hline Observations & 47 & 47 & 47 & 47 & 47 & 47 & 47 & 47 \\
\hline
\end{tabular}

Table II: Unit root test results of the variables

\begin{tabular}{|l|l|l|l|l|l|}
\hline \multirow{2}{*}{ VARIABLE } & \multicolumn{2}{l|}{ ADF } & \multicolumn{2}{l|}{ Phillips-Perron } & DECISION \\
\cline { 2 - 6 } & Level & $1^{\text {st }}$ Difference & Level & $1^{\text {st }}$ Difference & \\
\hline $\mathrm{In}\left(\mathrm{CO}_{2}\right)$ & -0.87 & $-6.71^{* * *}$ & -0.91 & $-6.73^{* * *}$ & $\mathrm{I}(1)$ \\
\hline $\mathrm{In}(\mathrm{FD})$ & -1.92 & $-8.89^{* * *}$ & -1.82 & $-8.89^{* * *}$ & $\mathrm{I}(1)$ \\
\hline In(ENERGY) & -0.05 & $-5.57^{* * *}$ & -0.183 & $-5.45^{* * *}$ & $\mathrm{I}(1)$ \\
\hline In(FDI) & $-5.28^{* * *}$ & $-8.98^{* * *}$ & $-5.48^{* * *}$ & $-17.60^{* * *}$ & $\mathrm{I}(0)$ \\
\hline In(GDP) & $-5.76^{* * *}$ & $-9.19^{* * *}$ & $-5.76^{* * *}$ & $-14.29 * * *$ & $\mathrm{I}(0)$ \\
\hline In(NATURAL Resources) & -2.09 & $-8.84^{* * *}$ & -2.07 & $-8.87^{* * *}$ & $\mathrm{I}(1)$ \\
\hline In(POP) & -0.95 & $-3.50^{* *}$ & 0.58 & $-3.45^{* *}$ & $\mathrm{I}(1)$ \\
\hline In(TRADE) & -1.61 & $-7.69^{* * *}$ & -1.53 & $-7.82^{* * *}$ & $\mathrm{I}(1)$ \\
\hline
\end{tabular}

$(* * *),(* *)$, means the series is stationary at $1 \%$, and $5 \%$ respectively, all tests were done with intercepts only

Table III: The Results of ARDL bounds test

\begin{tabular}{|c|c|c|c|}
\hline Model & $\begin{array}{l}\text { F } \\
\text { Statistic }\end{array}$ & Diagnostic tests & Decision \\
\hline $\begin{array}{l}\mathrm{CO}_{2}=\mathrm{F}(\mathrm{FD}, \quad \text { Energy,FDI, } \\
\text { GDP,N.rent, POP, Trade) }\end{array}$ & 1.4 & $\begin{array}{l}\text { Normality }=0.738 \\
\text { Serial corre }=0.55 \\
\text { Heteroscedasticity }=0.40\end{array}$ & No cointegration \\
\hline $\begin{array}{l}\mathrm{FD}=\mathrm{f}\left(\mathrm{CO}_{2}, \quad \text { Energy,FDI, GDP, }\right. \\
\text { N.Rent, POP, Trade })\end{array}$ & $5.6 * * *$ & $\begin{array}{l}\text { Normality }=0.97, \quad \text { Serial corr }=0.26 \text {, } \\
\text { Heteroscedasticity }=0.71\end{array}$ & $\begin{array}{l}\text { Cointegration } \\
\text { exists }\end{array}$ \\
\hline $\begin{array}{l}\text { Energy }=\mathrm{f}\left(\mathrm{CO}_{2}, \text { FD, FDI, GDP, }\right. \\
\text { N,Rent. POP,Trade) }\end{array}$ & 1.88 & $\begin{array}{l}\text { Normality }=0.20, \text { Serial corr }=0.28 \\
\text { Heteroscedaasticity }=0.57\end{array}$ & No cointegration \\
\hline $\begin{array}{l}\mathrm{FDI}=\mathrm{f}\left(\mathrm{CO}_{2}, \mathrm{FD}, \text { Energy, GDP, }\right. \\
\text { N.Rent, POP, Trade })\end{array}$ & $6.3 * * *$ & $\begin{array}{l}\text { Normality }=0.803, \text { Serial correl }=0.54 \\
\text { Heteroscedasticity }=0.34\end{array}$ & $\begin{array}{l}\text { Cointegration } \\
\text { Exists }\end{array}$ \\
\hline $\begin{array}{l}\mathrm{GDP}=\mathrm{f}\left(\mathrm{FD}, \quad \mathrm{CO}_{2}, \text { Energy, }\right. \\
\text { N.Rent, POP, Trade) }\end{array}$ & $4.7 * * *$ & $\begin{array}{l}\text { Normality }=0.45, \text { serial corre }=0.46 \\
\text { Heteroscedasticty }=0.77\end{array}$ & $\begin{array}{l}\text { Cointegration } \\
\text { exists }\end{array}$ \\
\hline $\begin{array}{l}\text { Nautural Rent }=\mathrm{f}\left(\mathrm{FD}, \mathrm{CO}_{2} \text {, Energy, }\right. \\
\text { FDI, GDP, POP, Trade) }\end{array}$ & $3.38 * *$ & $\begin{array}{l}\text { Normality }=0.52, \text { serial correl }=0.34 \\
\text { Heteroscedasticity }=0.68\end{array}$ & $\begin{array}{l}\text { Cointegration } \\
\text { exists }\end{array}$ \\
\hline $\begin{array}{l}\mathrm{POP}=\mathrm{f}\left(\mathrm{FD}, \quad \mathrm{CO}_{2}, \text { Energy, }\right. \\
\text { FDP, N.Rent, Trade) }\end{array}$ & 1.80 & $\begin{array}{l}\text { Normality }=047 \text { serial corre }=0.75 \\
\text { Heteroscedasticty }=0.22\end{array}$ & No cointegration \\
\hline $\begin{array}{l}\text { Trade }=\left(\mathrm{FD}, \mathrm{CO}_{2} \text { Energy, FDI, }\right. \\
\text { GDP, N.rent, POP })\end{array}$ & 2.35 & $\begin{array}{l}\text { Normality }=0.30 \text { serial corr }=0.79 \\
\text { Heteroscedasticity }=0.20\end{array}$ & No cointegration \\
\hline \multicolumn{4}{|l|}{ Critical values } \\
\hline Level & $10 \%$ & $5 \%$ & $1 \%$ \\
\hline $\mathrm{I}(1)$ & 3.52 & 4.01 & 5.06 \\
\hline $\mathrm{I}(0)$ & 2.45 & 2.86 & 3.74 \\
\hline
\end{tabular}


Table IV: Johansen and Juselius Cointegration test results

Table4 (a): Trace statistic

\begin{tabular}{|l|l|l|l|l|}
\hline Hypothesized No of CE(s) & Eigenvalue & Trace Statistic & 0.05 Critical value $^{\text {Prob }}$ & ** \\
\hline None* & 0.866460 & 252.1853 & 159.5297 & 0.0000 \\
\hline At most 1* & 0.691658 & 169.6377 & 125.6154 & 0.0000 \\
\hline At most 2* & 0.600809 & 121.3993 & 95.75366 & 0.0003 \\
\hline At most 3* & 0.539168 & 83.74838 & 69.81889 & 0.0026 \\
\hline At most 4* & 0.465653 & 51.98478 & 47.85613 & 0.0195 \\
\hline At most 5 & 0.432682 & 26.28968 & 29.79707 & 0.1202 \\
\hline At most 6 & 0.055900 & 3.049440 & 15.49471 & 0.9646 \\
\hline At most 7 & 0.016712 & 0.690973 & 3.841466 & 0.4058 \\
\hline
\end{tabular}

Trace test indicates 5 cointegrating eqs(s) at the 0.05 level,$*$ denotes rejection of the hypothesis at the 0.05 level, ** Mackinnon - HaugMichelis (1999) p-values.

Table IV(b) Maximum Eigen value-statistic

\begin{tabular}{|l|l|l|l|l|}
\hline Hypothesized No of CE(s) & Eigenvalue & Max-Eigen Statistic & 0.05 Critical value & Prob $^{* *}$ \\
\hline None* & 0.866460 & 82.54762 & 52.36261 & 0.0000 \\
\hline At most 1* & 0.691658 & 48.23836 & 46.23142 & 0.0301 \\
\hline At most 2 & 0.600809 & 37.65091 & 40.07757 & 0.0916 \\
\hline At most 3 & 0.539168 & 31.76360 & 33.87687 & 0.0875 \\
\hline At most 4 & 0.465653 & 25.69510 & 27.58434 & 0.0855 \\
\hline At most 5* & 0.432682 & 23.24024 & 21.13162 & 0.0249 \\
\hline At most 6 & 0.055900 & 2.358467 & 14.26460 & 0.9800 \\
\hline At most 7 & 0.016712 & 0.690973 & 3.841466 & 0.4058 \\
\hline
\end{tabular}

Trace test indicates 2 cointegrating eqs(s) at the 0.05 level,${ }^{*}$ denotes rejection of the hypothesis at the 0.05 level , ** Mackinnon - Haug-Michelis (1999) p-values.

Table V: Long run estimated coefficients: Dependent variable $\operatorname{In}\left(\mathrm{CO}_{2}\right)$

\begin{tabular}{|c|c|c|c|c|}
\hline & Model 1 & & Model 2 & \\
\hline Variable & Coefficient & Diagnostics & Coefficient & Diagnostics \\
\hline $\mathrm{C}$ & $\begin{array}{l}-25.5 * * * \\
(-5.01)\end{array}$ & \multirow{11}{*}{$\begin{array}{l}\text { Normality }=0.60 \\
\text { Serial corr }=0.90 \\
\text { Heteroscedasticty }=0.44 \\
\mathrm{R}^{2}=0.92\end{array}$} & $\begin{array}{l}-13.07 * * * \\
(-5.3)\end{array}$ & \multirow{11}{*}{$\begin{array}{l}\text { Normality }=0.73 \\
\text { Serial Corr }=0.62 \\
\text { Heteroscedasticity }=0.43 \\
\mathrm{R}^{2}=0.92\end{array}$} \\
\hline $\mathrm{InCO}_{2}(-1)$ & $\begin{array}{l}0.3 * * * \\
(3.0)\end{array}$ & & $\begin{array}{l}0.36^{* * * *} \\
(3.42)\end{array}$ & \\
\hline $\operatorname{In}(\mathrm{FD})$ & $\begin{array}{l}4.12 * * * \\
(2.5)\end{array}$ & & $\begin{array}{l}-0.07 \\
(-0.90) \\
\end{array}$ & \\
\hline $\operatorname{In}\left(\mathrm{FD}^{2}\right)$ & $\begin{array}{l}-0.67 * * * \\
(-2.58)\end{array}$ & & & \\
\hline In(Energy) & $\begin{array}{l}2.54 * * * \\
(6.21)\end{array}$ & & $\begin{array}{l}1.96^{* * *} \\
(5.30)\end{array}$ & \\
\hline $\operatorname{In}(\mathrm{FDI})$ & $\begin{array}{l}0.017 * * \\
(1.94)\end{array}$ & & $\begin{array}{l}0.015 \\
((1.47)\end{array}$ & \\
\hline $\operatorname{In}(G D P)$ & $\begin{array}{l}-0.004 \\
(-0.48)\end{array}$ & & $\begin{array}{l}0.004 \\
(0.296)\end{array}$ & \\
\hline $\operatorname{In}\left(G^{2} P^{2}\right)$ & & & $\begin{array}{l}-0.003 \\
(-0.45) \\
\end{array}$ & \\
\hline In(Natural Rent) & $\begin{array}{c}-0.18 * * * \\
(-4.24)\end{array}$ & & $\begin{array}{l}-0.145^{* * *} \\
(-3.19)\end{array}$ & \\
\hline $\operatorname{In}(\mathrm{POP})$ & $\begin{array}{l}0.21 * * \\
(2.02)\end{array}$ & & $\begin{array}{l}0.14 \\
(1.22) \\
\end{array}$ & \\
\hline In(Trade) & $\begin{array}{l}0.19 * * * \\
(2.5)\end{array}$ & & $\begin{array}{l}0.13 \\
(1.6)\end{array}$ & \\
\hline
\end{tabular}

t-values in brackets. $* * *, * *$, denotes significance at $1 \%$, and $5 \%$ respectfully 
Table VI: ECM estimated coefficients, dependent variable $\left(\Delta \mathrm{In} \mathrm{CO}_{2}\right)$

\begin{tabular}{|c|c|c|c|}
\hline Variable & Coefficient & t-ratio & Diagnostics \\
\hline $\mathrm{C}$ & 0.001729 & 0.728377 & \multirow{12}{*}{$\begin{array}{l}\text { Normality }(0.83) \\
\text { Serial corr }(0.21) \\
\text { Heteroscedasticty }(0.55)\end{array}$} \\
\hline $\mathrm{D}(\mathrm{FD})$ & $0.026048^{* * *}$ & 3.846180 & \\
\hline $\mathrm{D}(\mathrm{FD}(-1))$ & 0.000599 & 0.590441 & \\
\hline $\mathrm{D}\left(\mathrm{FD}^{2}\right)$ & $-0.000572 * * *$ & -4.230598 & \\
\hline $\mathrm{D}$ (Energy) & $0.001792 * * *$ & 6.630356 & \\
\hline $\mathrm{D}(\mathrm{FDI})$ & $0.007855^{* * *}$ & 2.839573 & \\
\hline $\mathrm{D}(\mathrm{FDI}(-1))$ & -0.003134 & -1.255709 & \\
\hline $\mathrm{D}(\mathrm{GDP})$ & $9.11 \mathrm{E}-05$ & 0.130440 & \\
\hline $\mathrm{D}$ (Natural rent) & $-0.011334 * * *$ & -3.885555 & \\
\hline $\mathrm{D}(\mathrm{POP})$ & $0.096976 * * * *$ & 1.899804 & \\
\hline $\mathrm{D}$ (trade) & $0.000677 * *$ & 2.003991 & \\
\hline $\operatorname{ECT}(-1)$ & $-0.695750 * * *$ & -4.358993 & \\
\hline
\end{tabular}

$* * *, * *$, denotes significance at $1 \%$, and $5 \%$ respectfully, in brackets are p-values

Table VII : Pair wise Granger Causality Tests

\begin{tabular}{|l|l|l|l|l|l|l|l|l|l|}
\hline \multirow{2}{*}{ Null Hypothesis } & Lag 1 & \multicolumn{2}{l|}{ Lag2 } & \multicolumn{2}{l|}{ Lag3 } \\
\cline { 2 - 14 } & Obs & F-stat & prob & Obs & F-Stat & Prob & Obs & F-Stat & Prob \\
\hline FD does not Granger Cause $\mathrm{CO}_{2}$ & 49 & 3.59 & 0.065 & 48 & 1.87 & 0.165 & 47 & 1.49 & 0.23 \\
\hline $\mathrm{CO}_{2}$ does not Granger Cause FD & 49 & 0.005 & 0.94 & 48 & 0.147 & 0.84 & 47 & 0.27 & 0.84 \\
\hline $\mathrm{GDP}_{\text {does not Granger Cause CO }}$ & 46 & 0.097 & 0.76 & 44 & 0.18 & 0.83 & 42 & 0.10 & 0.95 \\
\hline $\mathrm{CO}_{2}$ does not Granger Cause GDP & 46 & 3.39 & 0.073 & 44 & 3.43 & 0.04 & 42 & 2.65 & 0.06 \\
\hline GDP does not Granger Cause FD & 46 & 0.22 & 0.64 & 44 & 5.2 & 0.0095 & 42 & 1.98 & 0.13 \\
\hline FD does not Granger Cause GDP & 46 & 0.17 & 0.67 & 44 & 0.67 & 0.52 & 42 & 0.48 & 0.69 \\
\hline
\end{tabular}

